\title{
Causality between Foreign Portfolio Inflows and Economic Growth: Evidence from China and India
}

\author{
Fayyaz Ahmad ${ }^{1}$, Su-Chang Yang ${ }^{1} \&$ Muhammad Umar Draz ${ }^{2}$ \\ ${ }^{1}$ School of Economics, Lanzhou University, Lanzhou, Gansu Province, China \\ ${ }^{2}$ Faculty of Business and Information Science, UCSI University, Kuala Lumpur, Malaysia \\ Correspondence: Muhammad Umar Draz, Faculty of Business and Information Science, UCSI University, No. 1 \\ Jalan Menara Gading, Taman Connaught, Cheras, 56000 Kuala Lumpur, Malaysia. E-mail: \\ umardraz2626@gmail.com
}

Received: July 15, 2015

Accepted: August 17, 2015

Online Published: September 25, 2015

doi:10.5539/ijef.v7n10p163

URL: http://dx.doi.org/10.5539/ijef.v7n10p163

\begin{abstract}
The objective of this paper is to examine the causal relationship of foreign portfolio inflows and economic growth for two Asian economies, i.e. China and India. We have used Granger causality test for both countries' data ranging from 2001 to 2013 and concur with the findings of Durham (2003) and Duasa and Kassim (2009), i.e. there is no direct causality between foreign portfolio inflows and economic growth. Our results also suggest an indirect relationship between foreign portfolio inflows and economic growth of China and India.
\end{abstract}

Keywords: causality, China, economic growth, FPI, India

\section{Introduction}

With the rapid globalization and financial integration, foreign investment has undeniably become significant for both developed and developing economies; it is classified into two categories, namely foreign portfolio investment (FPI) and foreign direct investment (FDI). By and large, bilateral and multiple agreements among nations bring the cross-border investments. FPI is helpful to increase the depth and breadth of secondary market and enhances the market efficiency in developing nations. Since capital markets have become more advanced and the global liquidity is channeled through local markets; with increasing demand of foreign investors, the price earnings ratio increases in the host country and companies are able to raise capital at low cost. Consequently, low cost of capital enables the local companies to expand and diversify their production and leads towards GDP growth.

Apart from its contribution through market efficiency, FPI helps to finance the deficit of balance of payment and preserve the foreign currency reserves. As a result, the country can easily borrow funds from international financial institutions to stimulate its economic growth. FPI also plays an important role in promoting new companies, especially at the time of initial public offerings; ultimately these companies contribute towards the GDP.

FPI is a passive investment by overseas investors in shares, debentures and other financial assets. These investors are normally less informed as compared to FDI investors and do not take active part in the management. The primary concern of foreign investors, behind investment in any country, is to earn more and diversify risk. Therefore, economic growth is an essential factor to attract foreign investors. Rapid growth of an economy indicates smooth working of political and financial system of the country. Transparency in the stock market and good governance leads towards economic stability and an increase in GDP growth; during such period, corporations normally earn more profits and are able to pay more dividends. Thus, higher GDP growth results into higher amount of FPI inflows. Besides economic growth, better investor protection and suitable macroeconomic fundamentals applied by the emerging market economies (EMEs) urge the foreign investors to invest confidently.

Over the last two decades, capital flows towards EMEs were the result of financial integration between the developed and developing nations. As described by Humanicki, Kelm \& Olszewski (2013), the capital inflows towards EMEs were rather low during 1980s and early 1990s but grew rapidly in the mid-1990s. This change was triggered by a number of factors, e.g. expected profitability, lower risk and the worldwide environment shift 
regarding investment in EMEs. The hopes for relatively higher rate of return and the strong output growth of EMEs were the pull factors behind the scene. Moreover, loose monetary policy in the developed countries and the lower expected rate of return on financial assets added fuel to fire, and worked as push factors in the capital shift to developing countries.

With the aforementioned shift of capital, portfolio equity inflows had many positive effects on the recipient countries' economies, but at the same time, they have been blamed for the Mexican and Asian financial crisis of 1997. The sudden shift of foreign portfolio inflows can imbalance the potentially strong economies; therefore, Malaysia employed the capital controls in 1998 to stabilize its economy after crisis and various other nations also introduced capital reforms (Duasa \& Kassim, 2009).

Taking into consideration the Asian financial crisis of 1997, economic growth and global market share of China and India, it is useful to study the causality between foreign portfolio inflows and economic growth. Since both nations are among the leading economies in Asia and rivals to each other, our findings can be useful for other developing countries in the region. This study is split up into four sections. After a brief introduction and background of the topic, the existing literature has been reviewed. The next part comprises of statistical analysis of different variables related to the topic. Lastly, in the light of our findings, concluding remarks have been made along with implications for concerned authorities.

\section{Literature Review}

In the recent decades, financial integration, open markets and liberal trade policies are presumably very attractive for the foreign investors and have urged them to invest around the world. Foreign capital has been meeting the financial demands of developing countries in different forms; these forms are loans, official development assistance (ODA) foreign direct investment (FDI) and foreign portfolio investment (FPI). A major part of FPI has been flowing to the East Asia, Pacific and Latin America. USA and some European countries are the major investors in portfolio equity abroad.

The relative attractiveness of developing countries varies in terms of FPI inflows. Saudi Arabia is attractive for the USA and Japanese investors; Iran is a favorite destination for the Canadian, French and Italian investors, and Turkey attracts German and British investors. While diversifying asset portfolios, distance is also a hindrance in allocating the investment abroad and it affects FDI more than FPI. On the other hand, it exerts a similar impact on FDI and FPI in case of mergers and acquisitions, which is consistent with the fact that both are financial transactions with different ownership thresholds (Agarwal, 1997; Hattari \& Rajan, 2011; Abid \& Bahloul, 2011).

The existing literature on capital flows mainly focuses on the nature, behavior of foreign investors and contagion effects of foreign capital during a financial turmoil. Foreign investors generally invest in the form of FPI and FDI; the former is more volatile than the latter and investors more likely to receive liquidity shocks prefer FPI over FDI abroad. However, transparency and corporate governance in both capital markets can sometimes reduce the volatility differences between both investments. In developing countries, the ratio of FDI's volatility to other long term investments is smaller than the developed countries. Sometimes mass inflows of foreign investment turned out to be a catastrophe instead of a blessing.

It is generally believed that the benefits of foreign capital flows, especially FPI, are less than their cost. FPI and other foreign investments (OFIs) have no significant impact on growth and some results suggested that, OFIs have a negative impact on growth. Sudden shifts of international capital flows are credible evidence to the notion that financial liberalization was the culprit for the Asian financial crisis. Apart from unsustainable policies of the recipient countries, foreign portfolio investors were one of the main causes of this crisis. Domestic and international crisis can also interrupt the capital flows to a country; it occurred in Turkey when FPI inflows were strongly affected by the crisis of 2000 and FDI was strongly hit by the crisis of 2005-06 (Errunza, 2001; Goldstein \& Razin, 2002; Durham, 2003; Lajuni, Ooi, \& Ghazali, 2008; Uctum \& Uctum, 2011).

The current literature contains findings about foreign institutional investors (FIIs). Batra (2003) described that although FIIs involve in herding, no evidence is found that they are involved in destabilizing the Indian market. According to Karolyi (2002), foreign investors aggressively purchased Japanese equities during 1990s and it reached up to $12 \%$ of the total equity by 1997 . Before and during the Asian financial crisis of 1997, foreign investors' feedback was positive and stronger than the domestic investors in Japan. However, foreign investors in Taiwan involved in herding and withdrew their investment during the recession; as a result, the domestic investors performed well for the economy (Chun, 2013).

Previous studies, e.g. Knill (2005), Duasa and Kassim (2009), Boubakri et al. (2013) and Todea \& Pleşoianu (2013), are evident that foreign capital exerts both positive and negative impacts on the economy, but findings 
are not robust for all components. Economic growth of a country is a major pull factor to attract and retain the portfolio investors; a sound economic and political system is also very helpful to gain the foreign investors' confidence. Significant GDP growth and stable economic conditions are helpful to attract the new foreign investments and retain the present investors, but FPI does not contribute significantly towards GDP growth. Privatization also contributes significantly towards attracting FDI; however, its relationship with FPI is not that robust. FPI is an additional source of financing for small firms; although these flows are not harmful all the time, but it can hinder the growth of firms in a financial crisis. Regardless of short or long term dependence, there is a strong relationship between market efficiency and FPI which ultimately leads to economic prosperity.

\subsection{Research Gap}

The previous studies provide strong support to the argument that foreign capital inflows are necessary characteristic of the modern open market economy; particularly, emerging economies attracted an ample amount of capital since last couple of decades, but most of the work only focused on the instability and reversal effects of short term capital flows and associated these flows with turmoil.

\subsection{Contribution of the Paper}

Our work contributes to the literature by addressing the causal relationship of GDP and FPI. Since no previous study has focused on the comparative study of India and China, we aim to fill this research gap because China and India are Asian giants and both are ranked among the world fastest growing economies. Above all, both countries are competitors in the world market and enjoying a remarkable growth since the last decade. We have applied pair-wise causality to study the causal relation of both countries.

\subsection{Theoretical Background}

Increased integration among the financial markets has changed the horizon of investment opportunities and globalization has enabled the investors to have larger access to financial markets for portfolio investment. Investment theories including modern portfolio theory and capital asset pricing model demonstrated the benefits of portfolio and encouraged investors to hold the most diversified portfolio possible. Potential benefit from the growth differential of various countries is an important attraction for investors. Generally speaking, the growth rates of the developed countries are slower than the emerging ones, which attract more amounts of flows from overseas to take advantage of this differential. Nevertheless, given the fact that economies follow different cycle, investors prefer to invest in the less risky financial markets (Noman et al., 2015).

Because of its essential attributes of risk sharing and provide new source of funding, FPI emerged as an important alternative for highly indebted countries since 1980s. The transmission mechanism between FPI and GDP has been summarized in the previous studies, e.g. Errunza and Losq (1985), Obstfeld (1994), Errunza et al. (1998), Levine and Livine (2000), Errunza (2001), Perotti and Van (2001), Abdalla and Dafaalla (2011) and Todea and Pleşoianu (2013). FPI can influence domestic growth through its contribution in developing the local financial markets. In fact, there are a number of interrelated and reinforcing factors in this regard. FPI initiates informational, regulation and institutional changes because foreign participants demand timely quality information and minority right protection, as well as adequate trading and market regulations; it improves the quality and efficiency of financial sector and helps to boost up the domestic economy.

Active participation of foreign investors inculcates confidence among the local investors and market becomes more active to support policies and reforms. Liberalization of market is a signal of government commitment to market reforms, this will be helpful to strengthen trust between government and local investors and they will more actively participate in economic activities. Increasing market participation will also positively affect economic growth. Furthermore, FPI can promote free market culture in emerging markets by playing a disciplinary role, demanding managerial performance and monitoring activities. This will improve the shareholder value in domestic market. Capital market development, increased liquidity and better information flow will improve access to foreign exchanges and possibly reverse the capital flight. So, the contribution of FPI to market development, capital flights and potential taping of foreign savings, all contributes towards resource mobilization. However, FPI can also serve as complementary to foreign debt finance and increase the quality and quantity of international borrowing on national level. The ultimate result of all improvements is the economic uplift of country.

Integration among global markets, increased investment opportunities and active participation of foreign investors help domestic investors to hold well diversified portfolio. International risk sharing would allow them to reap the significant welfare gains because subsequent portfolio flows and expected returns would depend on global risk. This proposed to be less than domestic risk because of integration benefits. Hence, expected cost of 
capital will decline because of globalization. In addition, FPI will necessitate the development of various economic aspects including institutions, services, staff trainings and transfers. This will help investment banks to start joint venture or formed subsidiaries to serve domestic market.

To conclude the discussion, FPI can be influential to GDP growth by improving capital market development, enforcing the betterment of institutions, information, regulations, contributing to market growth and investor confidence, resource mobilization, reducing cost of capital and increasing welfare of investors by providing them diversification opportunities. Also, because of volatile nature extent and nature of relation varies depending upon local financial structure and policies. Although, Bekaert \& Harvey (2000) explored that popular beliefs regarding destabilizing influence of FPIs on local markets seems unwarranted, but nevertheless this cannot be ignored. Hence, empirical analyses are required to identify the impact of FPI on economic growth for India and China.

\section{Methodology and Results}

\subsection{Data and Variables}

The data set consists of annual observations of GDP, FPI, FDI, exchange rate and openness of country from 2001 to 2013. GDP data is collected from the World Bank. The source for FDI and openness data is United Nation Conference on Trade and Development UNCTAD, and consists of total FDI inflows. The level of openness is measured by exports and imports as suggested by Kyrkilis and Pantelidis (2003). FPI data are collected from the Coordinated Portfolio Investment Survey (CPIS) of International Monetary Fund (IMF). The survey collects information on cross-border portfolio investment directly from the reporting country. While, Exchange rate data is also collected from International Financial statistics, IMF. The relationship between FPI and GDP is influenced by FDI.

In literature, studies like Durham (2004), Baharumshah and Thanoon (2006), Balakrishnan et al. (2012) and Reinhardt et al. (2013) suggested the positive impact of both type of investment on economic growth. The relationship between liberalization and growth has extensive amount of investigation. The mechanism through economy openness generates positive impact on country suggested that, financial liberalization directly encourages inflow of capital. Financial liberalization also has an indirect effect on growth. By strengthening and fostering development of the domestic financial sector through imposing discipline on macroeconomic policies, it can lead to a more stable macroeconomic environment (Mirdala, 2006; Ahmed, 2010). FPI investors are basically speculators and take the advantage of market differentials in shape of growth, exchange rate fluctuations and other market differentials. Hence, exchange rate, Openness, FDI are used as control variables of our analyses.

The variables used in our analyses are abbreviated as follows:

$$
\begin{array}{lll}
\text { GDP }= & \text { Gross domestic production } & \{\text { Dependent Variable }\} \\
\text { FPI }= & \text { Foreign Portfolio Investment } & \{\text { Independent Variable 1\} } \\
\text { FDI }= & \text { Foreign Direct Investment } & \{\text { Independent Variable 2\} } \\
\text { OP }= & \text { Openness of Economy } & \{\text { Independent Variable 3 } \\
\text { ER }= & \text { Exchange Rate } & \{\text { Independent Variable 4 }
\end{array}
$$

The following hypothesis will be tested at $5 \%$ level of significance:

$\mathrm{H}_{0}=$ FPI has no significant causal relationship with GDP

$\mathrm{H}_{1}=$ FPI has significant causal relationship with GDP

\subsection{Statistical Analyses}

Our analyses consist of Granger Causality Test, which is based on the fact that future cannot be a reason of the past; however, the past can cause present or future. Statistically, if the past values of a variable Y significantly contribute to forecast the values of a variable $\mathrm{X}$, then $\mathrm{Y}$ is said to Granger cause $\mathrm{X}$. Therefore, by analyzing the past values of variables, we can determine the impact of FPI on GDP and vice versa. One-way causality between GDP and FPI can be described by four ways. If the estimated coefficients of FPI are statistically different from zero and the set of estimated coefficients of GDP are not statistically different from zero, then there is a unidirectional causality from FPI to GDP; and the opposite of this indicates unidirectional causality from GDP to FPI. When a set of coefficients of both variables in both regressions is statistically different from zero, the relationship is termed as bidirectional causality. Finally, when coefficients are not significant, it means no causality exists between both variables.

Our concern in this study is about FPI and GDP of China and India. Both variables can either influence each 
other or in a one way relationship. GDP is a basic element of observing performance, stability and future of the economy. Investors are concerned about safety of funds and their willingness is also driven by higher earnings expectations. GDP growth somehow insures investors that they can safely diversify their funds. On the other side, foreign capital bridges the investment gap for established and newly established corporations enhance market efficiency, and all these sectors contribute towards economic growth.

\section{Findings and Discussion}

The concept of stationary and non-stationary is important. A stationary series has a constant mean, variance and auto-covariance for each given lag. Many factors, as mentioned by Abdalla and Dafaalla (2011), can make a series non-stationary. These factors include seasonal factors, trends, and shocks and so on. All these factors should be separated from time series for correct evaluations. One of the methods to evaluate stationary or non-stationary series is Dickey-Fuller Test, but if disturbance term contains autocorrelation, DF test is invalid. PP test is robust in dealing with general form of Heteroskedasticity. We have used Augmented Dickey-Fuller test and Phillips-Perron test for unit root analyses. Following are the results of both tests:

Table 1. Unit root test for China

\begin{tabular}{lcccc}
\hline \multirow{2}{*}{ Variables } & \multicolumn{2}{c}{ Augmented Dickey-Fuller (ADF) Test } & \multicolumn{2}{c}{ Phillips-Perron (PP) Test } \\
\cline { 2 - 5 } & ADF test statistic & Critical value & PP test statistic & Critical value \\
\hline ER & -3.31 & -1.97 & -2.90 & -1.97 \\
FDI & $-4.56^{*}$ & -3.21 & $-9.39 *$ & -3.17 \\
FPI & $-3.70^{*}$ & -3.21 & $-6.41^{*}$ & -3.17 \\
GDP & $-4.07^{*}$ & -3.21 & $-3.19^{*}$ & -3.17 \\
OP & $-3.40^{*}$ & -3.21 & $-5.54^{*}$ & -3.17 \\
\hline
\end{tabular}

Source: Authors' analyses in Eviews.

Notes: 1 . Significance level is 5 per cent.

2. (*) means stationary of order I (I).

3. Both tests include intercept, except ER.

Table 2. Unit root test for India

\begin{tabular}{lcccc}
\hline \multirow{2}{*}{ Variables } & \multicolumn{2}{c}{ Augmented Dickey-Fuller (ADF) Test } & \multicolumn{2}{c}{ Phillips-Perron (PP) Test } \\
\cline { 2 - 5 } & ADF test statistic & Critical value & PP test statistic & Critical value \\
\hline ER & $-7.39 * *$ & -3.25 & $-3.59^{*}$ & -3.17 \\
FDI & $-3.71 *$ & -3.17 & $-3.71^{*}$ & -3.17 \\
FPI & $-5.22 *$ & -3.17 & $-6.40^{*}$ & -3.17 \\
GDP & $-4.12 *$ & -3.17 & -3.73 & -3.14 \\
OP & $-3.90^{*}$ & -3.21 & $-5.77^{*}$ & -3.17 \\
\hline
\end{tabular}

Source: Authors' analyses in Eviews.

Notes: 1 . Significance level is 5 per cent.

2. (*) means stationary of order I (I); (**) means stationary of order I (II).

3. Both tests include intercept.

The above-given results of ADF and PP test in table 1 and 2 depict that OP, FDI, FPI and GDP of China and India are stationary at first difference with intercept included for both PP and ADF tests. In case of china, ER is stationary at level without intercept. Since all variables are stationary, at 5\% of significance their data is reliable for further tests. Following are the results of Granger causality test:

Table 3. Granger causality test for China

\begin{tabular}{lccc}
\hline Pairs for Causality Test & F-Statistic & Probability & Causal Relationship \\
\hline$G D P \rightarrow$ FPI & 0.99 & $(0.42)$ & No \\
$F P I \rightarrow$ GDP & 3.037 & $(0.12)$ & No \\
& & & \\
$F D I \rightarrow$ FPI & 6.14 & $(0.035)$ & Yes \\
$F P I \rightarrow$ FDI & 6.44 & $(0.032)$ & Yes \\
\hline
\end{tabular}




\begin{tabular}{lccc}
\hline & & & \\
$O P \rightarrow$ FPI & 6.74 & $(0.029)$ & Yes \\
$F P I \rightarrow$ OP & 5.72 & $(0.040)$ & Yes \\
$E R \rightarrow$ FPI & 0.72 & $(0.52)$ & No \\
$F P I \rightarrow$ ER & 11.59 & $(0.008)$ & Yes \\
& & & No \\
$F D I \rightarrow$ GDP & 1.40 & $(0.31)$ & Yes \\
$G D P \rightarrow$ FDI & 5.78 & $(0.047)$ & Yes \\
& & & Yes \\
$O P \rightarrow$ GDP & 7.61 & $(0.027)$ & No \\
$G D P \rightarrow$ OP & 20.47 & $(0.002)$ & Yes \\
$E R \rightarrow$ GDP & & & No \\
$G D P \rightarrow$ ER & 2.46 & $(0.16)$ & No \\
$O P \rightarrow$ FDI & 14.24 & $(0.005)$ & No \\
$F D I \rightarrow$ OP & & & No \\
$E R \rightarrow$ FDI & 0.16 & $(0.85)$ & No \\
$F D I \rightarrow$ ER & 3.18 & $(0.11)$ & $(0.47)$ \\
$E R \rightarrow$ OP & & $(0.48)$ & \\
$O P \rightarrow$ ER & 0.83 & $(0.66)$ & $(0.65)$ \\
\hline
\end{tabular}

Source: Authors' analyses in Eviews.

The empirical results reported in Table 3 show that there is a bidirectional relationship between FPI and FDI of China i.e. FPI granger causes FDI and FDI granger cause FPI. Significant causal relationship between GDP and FDI of India also portrays the same but an indirect relationship among GDP and FPI (i.e. GDP $=>$ FDI $=>$ FPI). On the other hand, no direct relationship has been discovered between GDP and FPI. Our results are based on strong economic rationale. During the last two decades China and India have made significant strides in economic growth and market development for promoting international business environment. Between 2005 and 2007, about 28 percent of global foreign direct investment (FDI) inflows went to the developing world. In 2006, China received USD 69 billion or 5.3 percent of global FDI inflow. China's position as the largest recipient among developing countries has continued since the early 1990s, and thus it is not surprising that FDI is strongly influential on developing countries (UNCTAD, 2007; Ramasamy \& Yeung, 2010).

China's breathtaking development over the last three decades the scope, size and the rates of growth of both these economies has inspired the whole world. At present, China is significantly ahead of India in all defined merits; average annual growth, foreign investment and measures of society welfare as well (Kalyanaram, 2009). All these factors are an indicator of economic progress and stability; this in turn attracts both long and short term foreign capital flows. There is a two way causal relationship between FPI, openness and openness to GDP. This indicates that the foreign trade is strongly influential on both GDP and FPI. Trade links with the international community enhance knowledge and management skills of home country and enables them to reduce cost of capital by enjoying economies of scale. Growing production uplifts the economic growth, productivity and domestic investment and attracts foreign investors to come and invest for long and short run.

One way causality from FPI to exchange rate indicates the control measures to safeguard economy from speculative effects of FPI. Since 1994 China pegged its RMB with USD and adopted fixed exchange rate regime, which encourage FPI investors. As a control measure China appreciated RMB as a protection from speculation and inflation effects. There is always a tradeoff to control inflationary pressure because currency appreciation increases export price and affect international trade. Foreign trade is an integral part of Chinese economy circle around import exports. Exchange rate GDP unidirectional causality indicates relevant adjustments in terms of appreciation or depreciation of currency. Hence, movement of GDP leads to fluctuations in exchange rate. 
Table 4. Granger causality test for India

\begin{tabular}{|c|c|c|c|}
\hline Pairs for Causality Test & F-Statistic & Probability & Causal Relationship \\
\hline$G D P \rightarrow$ FPI & 0.24 & $(0.62)$ & No \\
\hline$F P I \rightarrow G D P$ & 0.46 & $(0.51)$ & No \\
\hline$F D I \rightarrow$ FPI & 5.86 & $(0.038)$ & Yes \\
\hline$F P I \rightarrow$ FDI & 13.18 & $(0.0054)$ & Yes \\
\hline$O P \rightarrow$ FPI & 1.94 & $(0.19)$ & No \\
\hline$F P I \rightarrow O P$ & 18.10 & $(0.0021)$ & Yes \\
\hline$E R \rightarrow$ FPI & 1.18 & $(0.30)$ & No \\
\hline$F P I \rightarrow \mathrm{ER}$ & 6.54 & $(0.030)$ & Yes \\
\hline$F D I \rightarrow$ GDP & 9.75 & $(0.99)$ & No \\
\hline$G D P \rightarrow$ FDI & 6.12 & $(0.035)$ & Yes \\
\hline $\mathrm{OP} \rightarrow \mathrm{GDP}$ & 0.25 & $(0.62)$ & No \\
\hline$G D P \rightarrow \mathrm{OP}$ & 23.69 & $(0.0008)$ & Yes \\
\hline$E R \rightarrow \mathrm{GDP}$ & 0.0004 & $(0.98)$ & No \\
\hline$G D P \rightarrow \mathrm{ER}$ & 1.016 & $(0.33)$ & No \\
\hline $\mathrm{OP} \rightarrow \mathrm{FDI}$ & 0.34 & $(0.56)$ & No \\
\hline$F D I \rightarrow O P$ & 0.046 & $(0.83)$ & No \\
\hline$E R \rightarrow$ FDI & 5.11 & $(0.050)$ & Yes \\
\hline$F D I \rightarrow E R$ & 0.41 & $(0.53)$ & No \\
\hline$E R \rightarrow \mathrm{OP}$ & 7.75 & $(0.021)$ & Yes \\
\hline$O P \rightarrow \mathrm{ER}$ & 6.26 & $(0.033)$ & Yes \\
\hline
\end{tabular}

Source: Authors' analyses in Eviews.

We can observe from Table 4 that, there is a bidirectional relationship where FPI granger causes FDI. Moreover, both GDP and FDI cause each other as well; but the outcome for causal relationship of GDP and FPI is not the same. In short, the aforementioned results portray that there is no significant direct causal relationship between GDP and FPI (and vice versa) in case of India. But there is also an indirect causality is running (i.e. GDP $\Rightarrow>$ FDI $\Rightarrow$ FPI). Among developing countries, India is enjoying impressive average annual growth rates since last decade. So GDP is the most important factor in attracting short and long term investment, and increases overseas trade as well. Although, both are ranked among the fastest growing economies but one of the major differences between China and India is political instability.

China enjoys a strong political structure and that is considered to be an asset compared to India's sometimes loud and energetic democracy. Causality between GDP, FPI, FDI and openness justifies that increasing domestic production stimulates foreign trade and more open policies from government. Hence, inflows of investment increase the efficiency and confidence of domestic investors as well. This in turn increases domestic participation. Exchange rate differentials are driving force in attracting short term flows in developing countries. But, same time surges of inflows increases instability and inflationary pressure. FPI and exchange rate causality indicates the counter measure to attract and manage these surges to protect economy from adverse effects. Because of less confidence of investors, market rumors could dry up these surges, especially in countries like India with instable political and social conditions.

Bidirectional causality between exchange rate and openness is obvious for India. The Indian currency is more fluctuating than China in terms of exchange rate. Depreciation of currency leads to raise exports, which is a positive indication towards openness. Furthermore, openness increase foreign activities, with exporting domestic goods country can increase foreign reserves and improve its balance of payment position. This helps to strengthen home currency. Finally, our results justify theoretical view that FPI indirectly influences the home 
country economic growth by improving different economic factors.

\section{Conclusion}

Along with its numerous benefits, globalization has provided foreign investors an opportunity to explore the equity markets worldwide. Though there is a lot of critique on whether or not foreign portfolio inflows are beneficial for the host country, however, the existing literature only points out herding behavior as the main issue. On the other hand, merits of FPI include market efficiency, capital for the newly established corporations and financing the deficit of balance of payments etc.

The aim of this study was to explore the causal relationship of FPI and GDP growth of China and India. The results of Granger Causality test illustrate that there is no direct causal relationship between both variables. These findings are similar with Durham (2003), and Duasa and Kassim (2009). However, it is interesting to note that there is indirect causal relationship between GDP growth and FPI inflows of China and India i.e. GDP granger causes FDI and the latter causes FPI.

This study has a definite clue towards indirect causal relationship between GDP growth and FPI, which shows that China and India needs sustainable economic growth in the future in order to attract the portfolio inflows. The policymakers must devise such strategies that will ensure the growth of both economies in the years to come. Since our work is based on the data of two countries only, a broader data set will be more suitable to generalize the results. This topic can be extended at the regional level e.g. South Asia, ASEAN, and the Middle East etc. for more reliable outcome.

\section{Acknowledgements}

The authors are thankful to Professor Dr. Jason Zezhong Xiao (Cardiff University, UK) and Assistant Professor Dr. Ananda Jeeva (UCSI University, Malaysia) for their valuable suggestions and comments.

\section{References}

Abdalla, S. Z., \& Dafaalla, H. A. (2011). Stock Market Development and Economic Growth in Sudan (1995-2009): Evidence from Granger Causality Test. Journal of Business Studies Quarterly, 93-105.

Abid, F., \& Bahloul, S. (2011). Selected MENA countries' attractiveness to G7 investors. Economic Modelling, 2197-2207. http://dx.doi.org/10.1016/j.econmod.2011.06.013

Agarwal, R. (1997). Foreign Portfolio Investment In Some Developing Countries: A Study of Determinants and Macroeconomic Impact. Indian Economic Review, 217-229. Retrieved from http://www.jstor.org/stable/29794138

Ahmed, A. D. (2010). Financial Liberalization, Financial Development and Growth Linkages in Sub-Saharan African countries: An Empirical Investigation. Studies in Economics and Finance, 314-339. http://dx.doi.org/10.1108/10867371011085156

Baharumshah, A. Z., \& Thanoon, M. A. M. (2006). Foreign capital flows and economic growth in East Asian countries. China Economic Review, 70-83. http://dx.doi.org/10.1016/j.chieco.2005.09.001

Balakrishnan, R., Nowak, S., Panth, S., \& Wu, Y. (2012). Surging Capital Flows to Emerging Asia: Facts, Impacts And Responses. Washington, D.C.: International Monetary Fund.

Batra, A. (2003). The Dynamics of Foreign Portfolio Inflows and Equity Returns in India. New Delhi: Indian Council for Research on International Economis Relations.

Bekaert, G., \& Harvey, C. (2000). Foreign Speculators and Emerging Equity Markets. Journal of Finance, 565-613. http://dx.doi.org/10.1111/0022-1082.00220

Boubakri, N., Cosset, J. C., Debab, N., \& Valéry, P. (2013). Privatization and globalization: An empirical analysis. Journal of Banking \& Finance, 1898-1914. http://dx.doi.org/10.1016/j.jbankfin.2012.12.014

Chun, P. H. (2013). The Influence of Foreign Portfolio Investment on Domestic Stock Returns: Evidence from Taiwan. The International Journal of Business and Finance Research, 1-11.

Duasa, J., \& H. Kassim, S. (2009). Foreign Portfolio Investment And Economic Growth in Malaysia. The Pakistan Development Review, 109-123. Retrieved from http://www.jstor.org/stable/41260915

Durham, J. B. (2003). Foreign Portfolio Investment, Foreign Bank Lending, and Economic Growth. Washington, DC: Federal Reserve System.

Durham, J. B. (2004). Absorptive Capacity And The Effects of Foreign Direct Investment And Equity Foreign Portfolio Investment on Economic Growth. European Economic Review, 285-306. 
http://dx.doi.org/10.1016/S0014-2921(02)00264-7

Errunza, V. (2001). Foreign Portfolio Equity Investments, Financial Liberalization, and Economic Development. Review of International Economics, 703-726. http://dx.doi.org/10.1111/1467-9396.00308

Errunza, V., \& Losq, E. (1985). International Asset Pricing Under Mild Segmentation: Theory and Test. Journal of Finance, 105-124. http://dx.doi.org/10.1111/j.1540-6261.1985.tb04939.x

Errunza, V., Lemma, S., \& Kedreth, H. (1998). The Pricing of Country Funds from Emerging Markets: Theory and Evidence. International Journal of Theoretical and Applied Finance, 111-143. http://dx.doi.org/10.1142/S0219024998000060

Goldstein, I., \& Razin, A. (2002). An Information-Based Trade Off Between Foreign Direct Investment and Foreign Portfolio Investment: Volatility, Transparency, and Welfare. Cambridge: National Bureau of Economic Research.

Hattari, R., \& Rajan, R. S. (2011). How Different are FDI and FPI Flows?: Distance and Capital Market Integration. Journal of Economic Integration, 499-525. http://dx.doi.org/10.11130/jei.2011.26.3.499

Humanicki, M., Kelm, R., \& Olszewski, K. (2013). Foreign Direct Investment and Foreign Portfolio Investment in the Contemporary Globalized World: Should they be still treated Separately? Warszawa: Narodowy Bank Polski.

Kalyanaram, G. (2009). India's Economic Growth and Market Potential: Benchmarked Against China. Journal of Indian Business Research, 57-65. http://dx.doi.org/10.1108/17554190910963208

Karolyi, G. A. (2002). Did the Asian financial crisis scare foreign investors out of Japan? Pacific-Basin Finance Journal, 411-442. http://dx.doi.org/10.1016/S0927-538X(02)00067-7

Knill, A. M. (2005). Taking the Bad with the Good: Volatility of Foreign Portfolio Investment and Financial Constraints of Small Firms. Maryland: World Bank. http://dx.doi.org/10.1596/1813-9450-3797

Kyrkilis, D., \& Pantelidis, P. (2003). Macroeconomic Determinants of Outward Foreign Drect Investment. International Journal of Social Economics, 827-836. http://dx.doi.org/10.1108/03068290310478766

Lajuni, N., Ooi, Y. A., \& Ghazali, M. F. (2008). Capital Controls: Impact on Foreign Direct Investment and Portfolio Investment in Malaysia 1991-2004. Global Journal of Business Research, 16-24.

Levine, R., \& Livine, L. R. (2000). International Financial Liberalization and Economic Growth. Review of International Economics, 688-702.

Mirdala, R. (2006). Macroeconomic Aspects of Financial Liberalization. Panoeconomicus, 439-456. http://dx.doi.org/10.2298/PAN0604439M

Noman, A., Rahman, M. N., \& Naka, A. (2015). Portfolio Investment Outflow and the Complementary Role of Direct Investment. Journal of Financial Economic Policy, 190-206. http://dx.doi.org/10.1108/JFEP-03-2014-0024

Obstfeld, M. (1994). Risk-Taking, Global Diversification and Growth. American Economic Review, 1310-1329. Retrieved from http://links.jstor.org/sici?sici=0002-8282\%28199412\%2984\%3A5\%3C1310\%3ARGDAG\% 3E2.0.CO\%3B2-8

Perotti, E., \& Van, O. P. (2001). Privatization, Market Development, and Political Risk in Emerging Economies. Journal of International Money and Finance, 43-69. http://dx.doi.org/10.1016/S0261-5606(00)00032-2

Ramasamy, B., \& Yeung, M. (2010). A Causality Analysis of the FDI-Wages-Productivity Nexus in China. Journal of Chinese Economic and Foreign Trade Studies, 5-23. http://dx.doi.org/10.1108/17544401011016654

Reinhardt, D., Ricci, L., \& Tressel, T. (2013). International Capital Flows and Development: Financial Openness Matters. Journal of International Economics, 235-251. http://dx.doi.org/10.1016/j.jinteco.2013.07.006

Todea, A., \& Pleşoianu, A. (2013). The influence of foreign portfolio investment on informational efficiency: Empirical evidence from Central and Eastern European stock markets. Economic Modelling, 34-41. http://dx.doi.org/10.1016/j.econmod.2013.03.017

Uctum, M., \& Uctum, R. (2011). Crises, portfolio flows, and foreign direct investment: An application to Turkey. Economic Systems, 462-480. http://dx.doi.org/ 10.1016/j.ecosys.2010.10.005

UNCTAD. (2007). World Investment Report. New York: United Nations. 


\section{Copyrights}

Copyright for this article is retained by the author(s), with first publication rights granted to the journal.

This is an open-access article distributed under the terms and conditions of the Creative Commons Attribution license (http://creativecommons.org/licenses/by/3.0/). 